\title{
The effects of Carroll's CSR Pyramid on Consumer Buying Behaviour: Case of Mobile Telephone Network (MTN) Company Bamenda Branch, Cameroon
}

\author{
Iden Blanche Mbonifor ${ }^{1}$, Noumigue Guy Roland Kenmegni ${ }^{2}$ \\ ${ }^{I}$ Student, Department of Management and Entrepreneurship, Higher Institute of Commerce and Management, The University of \\ Bamenda, Cameroon \\ ${ }^{2}$ Lecturer, Department of Management and Entrepreneurship, Higher Institute of Commerce and Management, The University of \\ Bamenda, Cameroon
}

\begin{abstract}
This paper attempts to explore the effect of the components of Corporate Social Responsibility (CSR) on Consumer Buying Behaviour (CBB). A questionnaire was administered to 110 consumers of MTN's products in Bamenda, Cameroon. The results of descriptive, correlation and regression analysis showed that: Bamenda consumers are partially aware of CSR concept, only the ethical responsibility of MTN has a significant relationship with $\mathrm{CBB}$, while the economic, legal and philanthropic responsibilities of MTN do not influence CBB. This means that the Bamenda MTN's consumers do not think about economic, legal and philanthropic responsibilities when they take their buying decision. Some of the major recommendation is that MTN should communicate more on their legal aspects. For instance, if MTN opens up to the public about its legal activities and on how the company abides with state laws, the public may gain interest in the legality of the company which may go a long way to have an effect on sales, turnover and finally social and financial performance. The current philanthropic works undertaken by MTN foundation like working with communities, giving to charity and visiting orphanages should be improved upon by taking up activities like aiding victims of the crisis.
\end{abstract}

Keywords: Bamenda, Cameroon, Consumer buying behaviour, Corporate social responsibility.

\section{INTRODUCTION}

G lobally in the past, the attention toward companies and $\mathbf{J}_{\text {whether they were socially responsible or not was not of }}$ interest to the population, households, consumers and others stakeholders. Companies could cause pollution and get away with it without paying any fine or incurring losses. This is not the case nowadays, since implementing or taking into account a corporate social responsibility (CSR) policy has several advantages for firms (Geethamani, 2017). The level of awareness on CSR is at the rising trend among consumers these days. Consumers nowadays have set a higher level of expectation towards the companies and so CSR can no longer be neglected if the business would like to grow up (Chow \& Chen, 2012). Managers need to define policies to satisfy all the stakeholders. These stakeholders include shareholders, workers, customers, suppliers and community organizations (Freeman, 1994).

In Africa, there is still a lagging in some countries when it comes to the responsibility of companies to their society. However, several studies have been carried out on CSR practices (policies) in Sub Saharan African countries. Rampersad and Skinner (2014) in their paper, explored how leading companies report on CSR practices in five SubSaharan Africa countries namely: Ghana, Nigeria, Cameroon, Kenya, and South Africa. GIZ (2013) presents profiles for twelve selected sub Saharan Africa countries reporting on their level of CSR awareness, understanding and implementation.

In Cameroon, CSR concept is gradually adopted and considered. In their exploratory study clarifying the concept of CSR and representing the state of play of CSR in Cameroonian companies, Moskolaï et al. (2016) brought out four manager's attitudes/ strategies towards CSR, namely: the reluctant, the reactive, the adaptive and the proactive. Examining and evaluating a Cameroonian hydro-electrical company CSR policies and activities in the local communities surrounding two of its reservoir dams at Mape and Bamendjing, the finding from Ndzi (2016), indicates that ENEO's CSR practices have not been efficient and very limited in these areas, surely because the expectation that the local inhabitants have on ENEO is very high in terms of sustainable development. Boubakary and Moskolaï (2016) demonstrate that the implementation of a CSR approach significantly influenced Cameroonian business strategies. In another research, Tchatchoua et al. (2018) reveal that human resources, consumers and to a lesser extent the community are the stakeholders whose wellbeing is of concern to SME's owners and/or managers. Many studies have been conducted in CSR taking into consideration corporations' point of view (Djoutsa \& Hikkerova, 2014; Sotamenou, 2014), however, limited studies considered CSR from consumer's perspective. 
Some research has already been conducted on the impact of CSR activities on consumer buying patterns (Khamah et al., 2015; Eshra \& Beshir, 2017; Potluri et al., 2020), but none of these have focused on consumers of telecommunication's products and services in Cameroon and Bamenda particularly. Hence the objective of this paper is to investigate the effect of the components of CSR (components according to Caroll) on Consumer Buying Behaviour (CBB), taking into consideration the case of Mobile Telephone Network (MTN) Cameroon Bamenda.

The implementation of CSR has been found to have a significant impact on increasing the sales of the company. Thanh et al. (2021) demonstrate a positive and significant impact of corporate/ social responsibility on firms' performance through mediating role of corporate reputation and customers' purchasing intention. Some of the main findings in CSR literature have shown that consumers are interested in the social behaviour of firms, and this behaviour positively influences their purchasing decision (Butt, 2016).

Cameroon has been highlighted as one of the countries in Africa in which large businesses promote the practice of CSR primarily through philanthropic projects in health, education and poverty reduction (Rampersad \& Skinner, 2014). Very few companies in Cameroon partake in corporate social work and MTN through its foundation is one of the few. The decision to become a customer of MTN Cameroon is a very important one because customers tend to stay loyal to a particular network service over long periods of time which brings about the assumption that CSR information will also be processed as part of decision making process. This study aims to help MTN to overcome some of the challenges (identify by Ngaundje \& Kwei, 2021) in implementing CSR policy. The rest of the paper will focus on literature review, methodology, results and conclusion respectively.

\section{LITERATURE REVIEW AND HYPOTHESES}

This section covers the literature review. It offers an explanation of the key concepts of the inquiry, explores theories related the subject matter at hand and reviews works related to the matter under investigation.

\subsection{MTN and Corporate Social Responsibility (CSR)}

CSR programs has its roots in corporate philanthropy whereby a wealthy businessman and philanthropist Andrew Curnegie challenged wealthy people to support social causes. Howard Bowen an American Economist and Grinnell College president is often cited as the 'father of CSR'. He connected the responsibility of corporations to society and published a book in 1953, which advocated for business ethics and responsiveness to societal stakeholders called "Social Responsibilities of the Businessman". Nevertheless, there is no one generally accepted definition of CSR. Table 1 consist of some authors who have written on CSR and their respective definition on the concept.
Table 1: Summary of some CSR definitions

\begin{tabular}{|c|c|}
\hline Authors & Definition \\
\hline Bowen (1953) & $\begin{array}{l}\text { The obligation of businessmen to pursue } \\
\text { those policies, to make those decisions or } \\
\text { to follow those lines of actions that are } \\
\text { desirable in terms of objectives and } \\
\text { values of our society. }\end{array}$ \\
\hline Carroll (1991) & $\begin{array}{l}\text { Social responsibility of business } \\
\text { encompasses the economic, legal, ethical } \\
\text { and philanthropic that society has of } \\
\text { organization at a given point in time. }\end{array}$ \\
\hline Brown \& Dacin (1997) & $\begin{array}{l}\text { A corporate status and activities with } \\
\text { respect to its perceived societal or, at } \\
\text { least, stakeholder obligations. }\end{array}$ \\
\hline $\begin{array}{c}\text { Matten \& Moon } \\
\qquad(2004)\end{array}$ & $\begin{array}{l}\text { CSR is a cluster concept which overlaps } \\
\text { with such concepts as business ethics, } \\
\text { corporate philanthropy, corporate } \\
\text { citizenship, sustainability, and } \\
\text { environmental responsibility }\end{array}$ \\
\hline ISO $26000(2010)$ & $\begin{array}{l}\text { CSR refers to the principles of social } \\
\text { responsibility by guaranteeing all } \\
\text { stakeholders about concerns relating to } \\
\text { societal and environmental activities and } \\
\text { transparent and ethical behavior, } \\
\text { contributing therefore to sustainable } \\
\text { development (SD) and the well-being of } \\
\text { society. }\end{array}$ \\
\hline Ollong \& Ndzi (2016) & $\begin{array}{l}\text { CSR is defined as companies' voluntary } \\
\text { action to improve social welfare, } \\
\text { economic condition, and the environment } \\
\text { through strategically planned projects that } \\
\text { ensure sustainable benefits for } \\
\text { stakeholders and local communities. }\end{array}$ \\
\hline
\end{tabular}

Source: Authors' from literature review

With its about 20 years of service in Cameroon, MTN has contributed to the economic growth of the country by investing more than 1000 billion CFA Francs for the development and maintenance of its infrastructure in the 10 regions of the country. In MTN's existence so far in the country, it has also paid a sum of 1000 billion CFA Francs to the state coffers in the form of taxes, custom duties, licensing fees and other royalties. MTN also brings millions of Cameroonians from different regions, divisions, districts and town closer on a daily basis by making it possible to get in touch with one another as the company covers $95 \%$ of the population. MTN has also helped in reducing the rate unemployment in Cameroon by creating more than a thousand direct jobs and over 200,000 indirect jobs. MTN also go above its core business to help communities when it comes to health, education and access to drinking water through MTN Foundation (Mobil Technology Network [MTN], 2021).

\subsection{Consumer buying behaviour}

Consumer buying behavior refers to the selection, purchase and consumption of goods and services for the satisfaction of their wants (Ramya \& Mohamed, 2016). CBB goal is to understand the buyer decision making process, both individually and in groups. Kotler (1994) defines CBB as the study of how people buy, what they buy, when they buy and why they buy. Consumer behaviour includes mental, physical and emotional activities which people do when they want to select, purchase, use or throw away the product or the service 
that fulfills their needs and demands (Vahdati et al., 2015). Ramya \& Mohamed (2016) suggest five factors that influence CBB which are: internal or psychological, social, cultural, economic and personal factors.

\subsection{The pyramid of corporate social responsibility}

Carroll (1991) proceeded to create a pyramid of CSR to better explain the four aspects of CSR cited in the definition. This pyramid is shown on figure 1 .

Figure 1: Pyramid of CSR

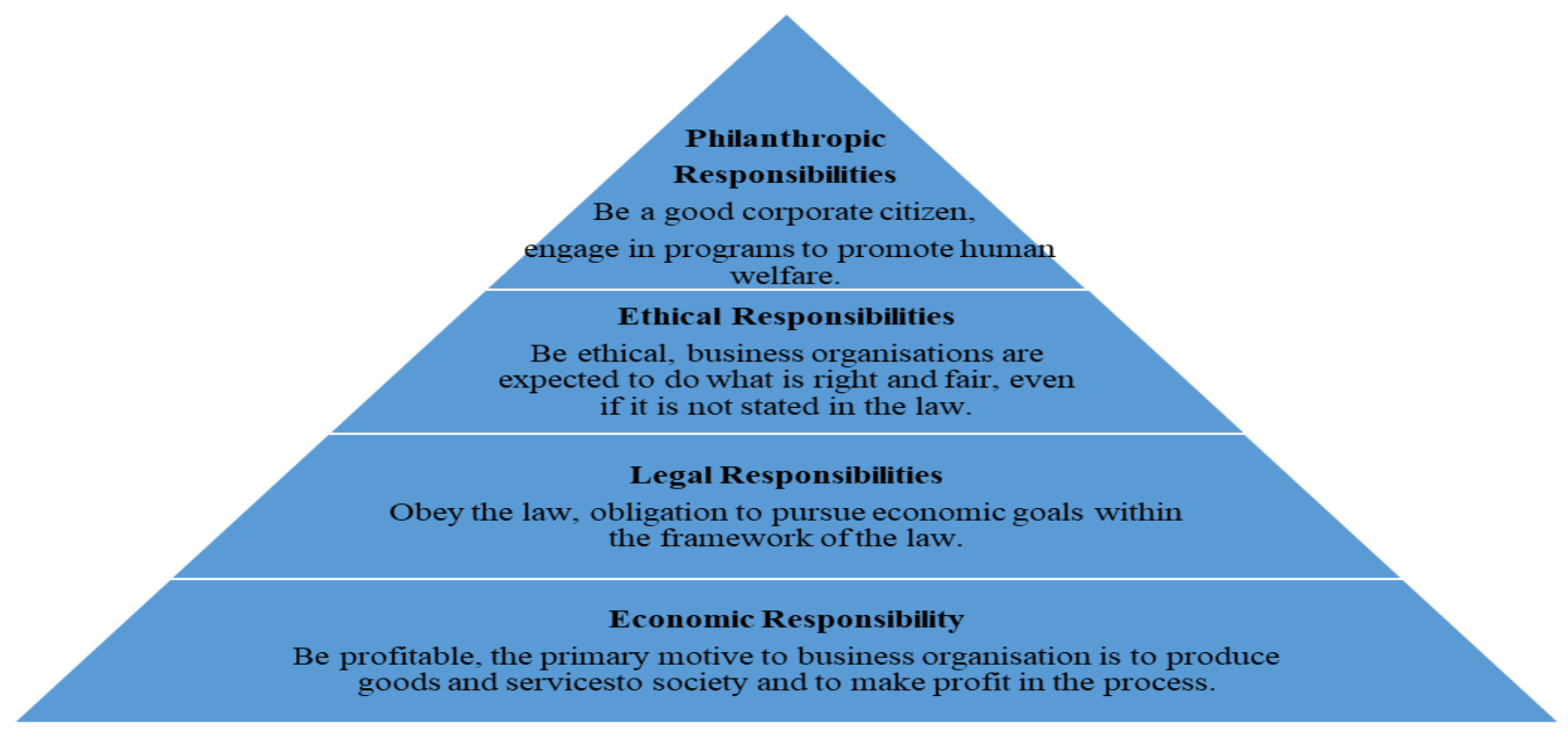

Source: Carroll (1991)

According to Carroll (1991), CSR is made of four main components which are; economic responsibilities, legal responsibilities, ethical responsibilities and philanthropic or discretionary responsibilities. This pyramid relies on the fact that various components are placed on top of the other having economic responsibilities at the base and philanthropic responsibilities at the top in the form of a pyramid. The components of Economic responsibility include: profitability which is the first priority, maintaining a strong competitive position is also an important target when it comes to economic responsibility, efficient operation is a must. With legal responsibility, it is important to obey the laws and other local regulations. A successful firm is the one that fulfills its legal obligations. Providing goods and services that fulfills its legal obligations is key to keep the firm running. Ethical responsibility goes beyond laws and regulations. Ethical norms should be recognized and respected and must not be compromised to achieve corporate goals. Philanthropic responsibility meaning managers and employees should participate in voluntary and charitable activities in their local communities. The organization may provide assistance to the local educational institutions and also contribute to those projects that improve the community's 'quality of life' is important. The logic behind the pyramid is that firms are expected to aim for profit maximization but it must also carter for other responsibilities which are to comply with the law, comply with the rules of the society and finally act as a good corporate citizen.

\subsection{Stakeholder theory}

A major reason that justifies the motivation of companies to invest in CSR programs falls within the domain of stakeholder theory. Stakeholder theory suggests that organizational survival and success is contingent on satisfying both its economic (profit maximization for example) and noneconomic (corporate social performance for example) objectives by meeting the needs of the company's various stakeholders (Pirsch et al., 2007).

Donaldson and Preston (1995) identify and present four theses/ aspects of stakeholder theory -descriptive/ empirical, instrumental, normative and managerial.

The stakeholder theory is descriptive: it presents a model describing what the corporation is. It describes the corporation as a constellation of cooperative and competitive interests possessing intrinsic value. The stakeholder theory is instrumental: It establishes a framework for examining the connections, if any, between the practice of stakeholder management and the achievement of various corporate performance goals. The stakeholder theory fundamental basis is normative and involves acceptance of the following ideas: (a) Stakeholders are persons or groups with legitimate interests in procedural and/or substantive aspects of corporate activity. (b) The interests of all stakeholders are of intrinsic value. The stakeholder theory is managerial in the broad sense of that term. It does not simply describe existing situations or predict cause-effect relationships; it also recommends attitudes, structures, and practices that, taken 
together, constitute stakeholder management. The stakeholder model of the contrasting models of corporation identify four additional stakeholders namely: governments, political groups, communities and trade associations, in addition to the stakeholders of the input output model: investors, customers, suppliers and employees.

Motivation for satisfying stakeholder demands stems from the fact that addressing stakeholder needs can be correlated with a firm's survival, economic well-being, competitive advantages, and the development of trust and loyalty among its targeted customers (Mitchell, 1997).

\subsection{Hypothesis}

The hypothesis were developed based on Carroll's CSR components and also findings from past researches and an effort to find the effect of CSR on CBB.

\section{Economic responsibility and consumer buying behaviour}

Safi and Ramay (2013) using a survey to collect data in Pakistan and exploiting the correlation analysis, finds a positive correlation between economic responsibility and CBB. From the Structural Equation Modeling (SEM) technique, the results from Yasir and Amjad (2021), depicted that the buyers of detergent brands in Pakistan are mostly attracted towards the economic level of the CSR pyramid. Mulaessa and Wang (2017) found similar result in a study carried out on Chinese's consumers. Hence the following hypothesis is stated:

$\mathrm{H}_{0}$ 1: Economic responsibility of MTN does not influence consumer buying behaviour.

\section{Legal responsibility and consumer buying behaviour}

In a study carried out in India, after making use of the binary logistics regression model Sharma and Sharma (2013) found a negative relationship between legal responsibility practices of the company with CBB. Huang et al. (2019) found comparable result in Vietman. In opposition, Rahim et al. (2011) revealed a significant relationship between legal responsibility and $\mathrm{CBB}$. Hence the following hypothesis is formulated.

$\mathrm{H}_{0}$ 2: Legal responsibilities of MTN do not influence consumer buying behaviour.

\section{Ethical responsibility and consumer buying behaviour}

Rahim et al. (2011) carried out a research aimed at examining the influence of CSR on the buying behaviour of Malaysian consumers and whether they consider a corporation's CSR initiatives before making any purchase decisions of the products and services, their results showed a significant relationship between ethical responsibility and CBB. Ferrell et al. (2019) showed that ethical practices are significantly linked with customer well-being. So the third hypothesis is formulated:

$\mathrm{H}_{0}$ 3: The ethical responsibility of MTN does not influence consumer buying behaviour.

\section{Philanthropic responsibility and consumer buying behaviour}

A quantitative research design and hypothetical testing to explore philanthropic responsibility and customer purchase behaviour variables carried out by Kurniawati et al. (2018) showed a positive and significant effect of philanthropic responsibility towards customer purchase behaviour, Yasir and Amjad (2021) in their study also demonstrate the significant effect of philanthropic responsability on CBB in Pakistan. Therefore, the following hypothesis is stated:

$\mathrm{H}_{0} 4$ : The philanthropic responsibility of MTN does not influence consumer buying behaviour.

\section{METHODOLOGY}

The research methodology will include the design, sample, sampling method, instrumentation measurement and data analysis respectively.

\subsection{Design}

In this study, both the quantitative and descriptive research design was employed. Data is collected from respondents, through the use of a questionnaire, to assess the effect of CSR on CBB. The instruments used in the survey comprise of the components of CSR as stated by Carroll (1991), CBB and respondents' characteristics.

\subsection{Sample, sampling method and data collection procedure}

The study was carried out using convenience sampling. A convenience sample (as defined by the Encyclopedia of Survey Research Methods) is a type of non-probability sampling method where the sample is taken from a group of people easy to contact or to reach. Convenience sample is used because it allows the researcher to obtain basic data and trends regarding the study without complications of using a randomized sample. This research was carried out from midMay to ending June 2021.

The study is focused on the consumers of MTN products and services located in Bamenda, Cameroon. Bamenda, also known as Abakwa Town is located in Northwestern region of Cameroon (366 kilometers north-west of the capital city Yaoundé). The questionnaires were administered both online and face to face so as to meet people far and wide.

A total of 126 respondents participated in this survey but after some disqualifications, 110 questionnaires were finally used for the analysis. Out of the 110 respondents, 58 were females and 52 males. Respondents with ages 30 and below made up $60 \%$ of the sample size, most respondents have as highest level of education "Advanced level" making a percentage of $31.8 \%$. More details on respondents' background characteristics can be seen on table 2 . 
Table 2: Respondents’ Background Characteristics

\begin{tabular}{|c|c|c|c|}
\hline Variable & Categories & Frequency & Percent \\
\hline \multirow{2}{*}{ Gender } & Male & 52 & $47.3 \%$ \\
\hline & Female & 58 & $52.7 \%$ \\
\hline \multirow{5}{*}{ Age } & Less than 20 & 17 & $15.5 \%$ \\
\hline & $20-29$ & 49 & $44.5 \%$ \\
\hline & $30-39$ & 27 & $24.5 \%$ \\
\hline & $40-49$ & 14 & $12.7 \%$ \\
\hline & $50-59$ & 3 & $2.7 \%$ \\
\hline \multirow{6}{*}{$\begin{array}{l}\text { Education } \\
\text { level }\end{array}$} & Less than primary school & 2 & $1.8 \%$ \\
\hline & $\begin{array}{c}\text { First school Leaving } \\
\text { certificate }\end{array}$ & 4 & $3.6 \%$ \\
\hline & Ordinary level & 23 & $20.9 \%$ \\
\hline & Advance level & 35 & $31.8 \%$ \\
\hline & Bachelor degree & 30 & $27.3 \%$ \\
\hline & Master's degree or higher & 16 & $14.5 \%$ \\
\hline \multirow{5}{*}{ Occupation } & Student & 42 & $38.2 \%$ \\
\hline & Government Officer & 2 & $1.8 \%$ \\
\hline & Private Employee & 24 & $21.8 \%$ \\
\hline & Self Employed & 41 & $37.3 \%$ \\
\hline & General Contract & 1 & $0.9 \%$ \\
\hline
\end{tabular}

Source: Authors' survey.

\subsection{Dictionary of Variables and survey instrument}

The first template of the questionnaire was presented to ten consumers of MTN products in Bamenda to go through it for pretesting after which corrections were made to the questionnaire following the pretest. The aim of the pretesting was to make sure that the questions were not complex to answer. The questionnaire was designed in two parts. The first part gathers the respondent's demographic information. The second section contained statements used to assess Carroll's four components of CSR (economic, legal, ethical and philanthropic responsibilities), the statements used to assess CBB and one statement used to evaluate level of awareness of CSR concept by customer. The second part was designed using a five-point Likert scale ranging from ' 1 ' for 'strongly disagree' to ' 5 ' for 'strongly agree'. The CSR components and CBB are measured based on items adapted from Rahim et al. (2011), Carroll (1991) and Dusuki and Yusof (2008).

The reliability of the values used in this study was measured using the Cronbach alpha coefficient. The results in Table 3 suggests that the items have a relatively high degree of internal consistency as reliability coefficient of 0.70 or higher and is considered acceptable in social science research (Zikmund, 2003; Hair et al., 2006)
Table 3: Cronbach's alpha reliability coefficient

\begin{tabular}{|c|c|c|}
\hline Variables & $\begin{array}{c}\text { Number of } \\
\text { items }\end{array}$ & $\begin{array}{c}\text { Cronbach's alpha reliability } \\
\text { coefficient }\end{array}$ \\
\hline $\begin{array}{c}\text { Economic } \\
\text { Responsibility }\end{array}$ & 4 & 0.891 \\
\hline Legal Responsibility & 2 & 0.727 \\
\hline Ethical Responsibility & 2 & 0.843 \\
\hline $\begin{array}{c}\text { Philanthropic } \\
\text { Responsibility }\end{array}$ & 3 & 0.876 \\
\hline $\begin{array}{c}\text { Consumer Buying } \\
\text { Behaviour }\end{array}$ & 4 & 0.853 \\
\hline
\end{tabular}

Source: Authors' computation

\subsection{Data Analysis}

The technique used for the study was both the descriptive technique and inferential technique. The descriptive technique was used in analyzing the most agreed statement under each of the variables, while the inferential statistics was used to test the effect the independent variables have on the dependent variable, that is, to test the hypotheses $\mathrm{H}_{0} 1, \mathrm{H}_{0} 2, \mathrm{H}_{0} 3$ and $\mathrm{H}_{0} 4$ through the multiple regression analysis.

\section{RESULTS}

The key results of this study are summarized in table 4 to 8 . Table 4 comprises of the respondents stand on CSR and CBB, Table 5 exhibits correlation analysis results, while the tables 6 to 8 show multiple regression analysis results summary.

Table 4: Respondents stand on CSR and CBB

\begin{tabular}{|l|l|l|}
\hline Variables & $\mathrm{N}$ & $\mathrm{Mean}$ \\
\hline $\begin{array}{l}\text { Building the society is one of the responsibilities of } \\
\text { companies }\end{array}$ & 110 & 3.545 \\
\hline Economic responsibility & & 4.132 \\
\hline $\begin{array}{l}\text { A company should provide goods and services at } \\
\text { reasonable prices }\end{array}$ & 110 & 4.064 \\
\hline $\begin{array}{l}\text { A Company should be consistent in providing } \\
\text { competent goods and services }\end{array}$ & 110 & 3.964 \\
\hline $\begin{array}{l}\text { A company should make profit off the services and } \\
\text { goods it provides }\end{array}$ & 110 & 4.382 \\
\hline $\begin{array}{l}\text { A company should take care of the interest of its } \\
\text { owners }\end{array}$ & 110 & 4.118 \\
\hline Legal responsibility & 110 & 3.827 \\
\hline $\begin{array}{l}\text { I believe successful companies comply with all } \\
\text { state rules and regulations }\end{array}$ & 110 & 3.918 \\
\hline $\begin{array}{l}\text { I think a successful organization is one that fulfills } \\
\text { its legal obligations }\end{array}$ & 110 & 4.027 \\
\hline Ethical responsibility & 110 & 3.655 \\
\hline $\begin{array}{l}\text { A company should avoid doing harm to the } \\
\text { environment or society at all cost even if its costly } \\
\text { to them }\end{array}$ & 4.055 \\
\hline $\begin{array}{l}\text { A company does not go against the ethical norms } \\
\text { of the society in order to achieve its corporate } \\
\text { goals }\end{array}$ & 110 \\
\hline Philanthropic responsibility & 4.036 \\
\hline $\begin{array}{l}\text { Socially responsible organizations contribute more } \\
\text { to charitable organizations }\end{array}$ & 110 \\
\hline $\begin{array}{l}\text { Socially responsible companies commit resources } \\
\text { to support culture and arts }\end{array}$ & 110 \\
\hline $\begin{array}{l}\text { I use the products and services of an organization } \\
\text { because it sponsors projects that enhance a } \\
\text { community's "quality of life." }\end{array}$ & 4.155 \\
\hline
\end{tabular}




\begin{tabular}{|l|l|l|}
\hline Consumer buying behaviour & & 3.870 \\
\hline $\begin{array}{l}\text { If the price and quality of two products are the } \\
\text { same, I would buy from a firm that has a social- } \\
\text { responsible reputation }\end{array}$ & 110 & 3.9 \\
\hline $\begin{array}{l}\text { The purchase decisions of people can influence } \\
\text { firm's social activities }\end{array}$ & 110 & 4.036 \\
\hline I will buy more from a company that pays its tax & 110 & 3.818 \\
\hline $\begin{array}{l}\text { I will pay more for the products of a socially } \\
\text { responsible company }\end{array}$ & 110 & 3.727 \\
\hline
\end{tabular}

Source: Authors' computation

The first statement in Table 4, "Building the society is one of the responsibilities of companies" with a mean equal to 3.545 showed that MTN customers in Bamenda are partially aware of CSR concept.

Table 5: Correlation Matrix

\begin{tabular}{|c|c|c|c|c|c|}
\hline & $\begin{array}{c}\text { Eco_Res } \\
\text { p }\end{array}$ & $\begin{array}{c}\text { Legal_Res } \\
\mathrm{p}\end{array}$ & $\begin{array}{c}\text { Eth_Res } \\
\mathrm{p}\end{array}$ & $\begin{array}{c}\text { Phil_Res } \\
\mathrm{p}\end{array}$ & CBB \\
\hline Eco_Resp & 1 & & & & \\
\hline $\begin{array}{c}\text { Legal_Res } \\
\text { p }\end{array}$ & .178 & 1 & & & \\
\hline Eth_Resp & .146 & .167 & 1 & & \\
\hline Phil_Resp & .068 & .139 & -.032 & 1 & \\
\hline CBB & .156 & $.215^{*}$ & $.269^{* *}$ & .159 & 1 \\
\hline
\end{tabular}

*. Correlation is significant at the 0.05 level (2-tailed).

**. Correlation is significant at the 0.01 level (2-tailed).

Source: Authors' computation

Table 6 shows regression analysis outcomes that indicate the relation of economic, legal, ethical, and philanthropic responsibility (independent variables) on consumer buying behavior (dependent variable). The values of multi-correlation coefficients (R) can lie between -1 and +1 . According to the model summary of multi regressions in Table 6 , the multiple $\mathrm{R}$ is 0.361 , this means that there is a positive linear relationship between CSR elements and consumer buying behavior.

As it can be seen in Table 6, R-square is equal to 0.130 , this indicates that there is a weak linear relationship between CSR components and consumer buying behavior. Approximately $13 \%$ of the variance (the variation) in the CBB is explained by its linear relationship with CSR elements. And $87 \%$ of variation is due to chance or many additional factors like MTN service prices.

Table 6: Model summary on regression analysis results

Model summary

\begin{tabular}{|c|c|c|c|c|}
\hline Model & $\mathrm{R}$ & $\begin{array}{c}\mathrm{R} \\
\text { Square }\end{array}$ & $\begin{array}{c}\text { Adjusted R } \\
\text { Square }\end{array}$ & $\begin{array}{c}\text { Std. Error of the } \\
\text { Estimate }\end{array}$ \\
\hline 1 & $.361 \mathrm{a}$ & .130 & .097 & .78218 \\
\hline
\end{tabular}

a. Predictors: (Constant), Philanthropic, Ethical, Economic and Legal responsibilities

Source: Authors' computation

The analysis of variance (ANOVA) in Table 7 is used to test whether there is a significant or insignificant linear relationship between the four elements of CSR and consumer buying behavior. According to Table 7, the p-value is 0.005 which means that the CSR components are significant to CBB.

Table 7: ANOVA of multiple regression

ANOVA(b)

\begin{tabular}{|c|c|c|c|c|c|c|}
\hline Model & & $\begin{array}{c}\text { Sum of } \\
\text { Squares }\end{array}$ & $\mathrm{df}$ & $\begin{array}{c}\text { Mean } \\
\text { Square }\end{array}$ & $\mathrm{F}$ & Sig. \\
\hline 1 & $\begin{array}{c}\text { Regres } \\
\text { sion }\end{array}$ & 9.601 & 4 & 2.400 & 3.923 & $.005 \mathrm{a}$ \\
\hline & $\begin{array}{c}\text { Residu } \\
\text { al }\end{array}$ & 64.240 & 105 & .612 & & \\
\hline & Total & 73.841 & 109 & & & \\
\hline
\end{tabular}

a. Predictors: (Constant), Philanthropic, Ethical, Economic and Legal Responsibilities

b. Dependent Variable: CBB

Source: Authors' computation

Table 8: Coefficients of multiple regression

Coefficients (a)

\begin{tabular}{|c|c|c|c|c|c|c|}
\hline \multirow[t]{2}{*}{ Model } & & $\begin{array}{l}\text { Unstanda } \\
\text { rdized } \\
\text { Coefficie } \\
\text { nts }\end{array}$ & \multirow[t]{2}{*}{$\begin{array}{l}\text { Std. } \\
\text { Error }\end{array}$} & $\begin{array}{c}\text { Standar } \\
\text { dized } \\
\text { Coeffici } \\
\text { ents }\end{array}$ & \multirow[t]{2}{*}{$\mathrm{t}$} & \multirow[t]{2}{*}{ Sig. } \\
\hline & & B & & Beta & & \\
\hline \multirow[t]{5}{*}{1} & $\begin{array}{c}\text { (Constan } \\
\text { t) }\end{array}$ & 1.910 & .536 & & 3.562 & .001 \\
\hline & $\begin{array}{c}\text { Eco_Res } \\
\text { p }\end{array}$ & .075. & .080 & .087. & .932 & .354 \\
\hline & $\begin{array}{l}\text { Leg_ } \\
\text { Resp }\end{array}$ & .133 & .090 & .140 & 1.484 & .141 \\
\hline & $\begin{array}{l}\text { Eth_ } \\
\text { Resp }\end{array}$ & 171 & .067 & .238 & 2.550 & .012 \\
\hline & $\begin{array}{c}\text { Phil_Res } \\
\text { p }\end{array}$ & . 118 & .077 & . 141 & 1.530 & .129 \\
\hline
\end{tabular}

b. Dependent Variable: CBB

Source: Authors' computation

\subsection{Economic responsibility has no effect on MTN's consumer buying behaviour in Bamenda}

The analysis on the table 4 shows that majority of the respondents agreed with the statement "MTN should make profit off the services and goods it provides" this statement has a mean of 4.382 which is higher than the mean of the other statements. The statement with the lowest mean is "MTN should be consistent in providing competent goods and services" with a mean of 3.964. Table 5 shows that there is no correlation between Economic responsibility and CBB. The tendency is confirmed in table 8 , Economic responsibility has a p-value of 0.354 which is higher than 0.05 which indicates that Economic responsibility does not influence and MTN's $\mathrm{CBB}$ in Bamenda. Hence the null hypothesis $\left(\mathrm{H}_{0} 1\right)$ which states that economic responsibility of MTN does not influence CBB is accepted. This finding confirmed previous studies carried out in Egypt by Eshra and Beshir (2017) and in Pakistan by Yasir and Amjad (2021). 
4.2 Legal responsibility does not have a significant effect on MTN's consumer buying behaviour in Bamenda

Amongst the two statements defining the legal responsibility, the statement most respondents agreed to is "I think a successful organization (MTN) is one that fulfills its legal obligations" having a mean of 3.918. The least most agreed statement with a mean of 3.827 is "I believe successful companies (MTN) comply with all state rules and regulations". From table 5 and table 8 respectively, legal responsibility and CBB are correlated but this relation is not confirmed by regression analysis, Legal responsibility has a pvalue of 0.141 which is greater than 0.05 . Thus the alternative hypothesis $\mathrm{H} 2$ which states that the legal responsibilities of MTN influence CBB is not accepted. This result is in line with previous studies which show that there is no relationship between the legal practices of a company and CBB (Eshra \& Beshir 2017; Yasir \& Amjad (2021).

\subsection{Ethical responsibility has a significant effect on MTN's consumer buying behaviour in Bamenda}

"MTN should avoid doing harm to the environment or society at all cost even if its costly to them" is the most agreed statement under ethical responsibility with a mean of 4.027 while the least agreed statement with a mean of 3.655 is "A company does not go against the ethical norms of the society in order to achieve its corporate goals". The table 5 shows a significant correlation between Ethical responsibility and $\mathrm{CBB}$, this result is confirmed by regression analysis, the pvalue of ethical responsibility (0.012) is less than 0.05 implying that the null hypothesis $\mathrm{H}_{0} 3$ is not accepted. The ethical responsibility has a significant influence on MTN's $\mathrm{CBB}$, this finding confirmed previous studies (Rahim et al., 2011; Yasir \& Amjad, 2021) and contradict the study carried out by Eshra and Beshir (2017).

\subsection{Philanthropic responsibility does not have a significant effect on consumer buying behaviour}

Majority of respondents agreed that "Socially responsible companies (MTN) commit resources to support culture and arts" (mean of 4.155). The least agreed statement is "Socially responsible organizations contribute more to charitable organizations" with a mean of 4.036 . Table 5 shows that there is no correlation between Philanthropic responsibility and $\mathrm{CBB}$, Information from table 8 displaying linear regression analysis results, confirmed the insignificant effect of philanthropic responsibility ( $\mathrm{p}$-value $=0.129)$ on CBB. The null hypothesis $\mathrm{H}_{0} 4$ is accepted. This result is in conformity with Eshra and Beshir, (2017). The philanthropic actions put on by MTN have no effect on their customers purchasing behaviour.

\section{CONCLUSION}

The study sought to verify the following hypothesis: the economic responsibility of MTN does not influence CBB, the legal responsibilities of MTN do not influence $\mathrm{CBB}$, the ethical responsibility of MTN does not influences CBB and there is no relationship between philanthropic responsibility of a company and CBB. Considering the consumers of MTN products residing in Bamenda, findings showed that only one of the four components of corporate social responsibility identified by Carroll (1991) has a significant relationship with consumer buying behaviour that is, the ethical responsibility of MTN, while economic, legal and philanthropic responsibilities do not. Whether Bamenda branch of MTN comply with state rules and regulations, provides competent services and sponsors projects enhancing community's "quality of life" is not really of interest to the MTN's consumers and so do not affect their buying behaviour. The value of R-square shows that many others factors explained MTN's customers buying behaviour.

MTN through its foundation has to improve on their current philanthropic act of visiting orphanages, contributing to charity or investing in Cameroonian movie industry, by taking up activities like aiding those internally displaced as a result of the crisis. It would be of great advantage to those receiving help, the organization itself and on consumer's purchase decision. Considering the relationship between economic responsibility and CBB, MTN should also improve on that area by maybe giving better prices for their goods and/or services and making sure that they are available when needed to better influence the buying behaviour of their consumers. MTN should be more transparent on their legal aspects if they wish to win over more customers. The rules and regulations of the country should also be followed and taken seriously if MTN wishes to build a good relationship with the potential customers and possible consumers of the products offered by them. The implementation of these recommendations will improve the customer portfolio and the image/ reputation of this multinational in the country. This will in fact has a positive impact on its turnover and its social and financial performance.

\section{REFERENCES}

[1] Bhattacharya, C. B., \& Sen, S. (2004). Doing better at doing good: when, why, and how consumers respond to corporate social initiatives. California Management Review, 47, 9-24.

[2] Boubakary, \& Moskolaï, D. D. (2016). The influence of the implementation of CSR on business strategy: An empirical approach based on Cameroonian enterprises. Arab Economic and Business Journal, 11(162-171).

[3] Bowen, H. (1953). Social Responsibilities of the Businessman. Harper, New York.

[4] Brown, T.J., \& Dacin, P.A. (1997). The company and the product: Corporate associations and consumer product responses. Journal of Marketing, 61(1), 68-84.

[5] Butt, I. (2016). Corporate Social Responsibility and Consumer Buying Behavior in Emerging Market: A Mixed Method Study. International Journal of Business and Management, 11(7), 211222.

[6] Carroll, A. B. (1991). The pyramid of corporate social responsibility: toward the moral management of organizational stakeholders. Business Horizons, 34(July-August), 39-48.

[7] Carroll, A. B. (1999). Corporate social responsibility: evolution of a definitional construct. Business and Society, 38(3):268-295.

[8] Chow, W., \& Chen, Y. (2012). Corporate sustainable development: Testing a new scale based on the mainland Chinese context. Journal of Business Ethics, 105(4), 519-533. 
[9] Djoutsa W. L., \& Hikkerova, L. (2014). La responsabilité sociale d'entreprise dans les PME camerounaises : bilan, enjeux et perspectives. Gestion 2000. 31(6), 41-66.

[10] Donaldson, T., \& Preston, L. E. (1995). The stakeholder theory of the corporation: concepts, evidence, and implications. The Academy of Management Review, 20(1), 65-91.

[11] Dusuki, A.W., \& Mohd Yusof, T.F.M.T. (2008). The pyramid of corporate social responsibility model: empirical evidence from Malaysian stakeholders' perspectives. Malaysian Accounting Review, 7(2), 29-54.

[12] Eshra, N., \& Beshir N. (2017). Impact of corporate social responsibility on consumer buying behavior in Egypt. World Review of Business Research, 7(1), 32-44.

[13] Ferreira, A. I., \& Ribeiro, I. (2017). Are you willing to pay the price? The impact of corporate social (Ir) responsibility on consumer behaviour towards national and foreign brands. Journal of Consumer Behaviour, 16(1), 63-71.

[14] Ferrell, O. C., Harrison, D. E., Ferrell, L., \& Hair, J. F. (2019). Business ethics, corporate social responsibility, and brand attitudes: An exploratory study. Journal of Business Research, 95, 491-501.

[15] Freeman, R. E. (1994). The Politics of Stakeholder Theory. Business Ethics Quarterly, 4, 409-421.

[16] Gall, M. D., Borg, W. R., \& Gall, J. P. (1996). Education research, an introduction. New York: Longman Publishers.

[17] Geethamani, S. (2017). Advantages and disadvantages of corporate social responsibility. International Journal of Applied Research, 3(3), 372-374.

[18] GIZ. (2013). Promotion de la responsabilité sociétale des entreprises en Afrique subsaharienne: Note d'orientation basée sur un exercice de cartographie, GIZ.

[19] Hair, J. F. B., Babin, W.C., Anderson, J.B., \& Tatham, R. L. (2006). Multivariate data analysis. NJ: Prentice Hall.

[20] Huang, Y. F., Do, M. H., \& Kumar, V. (2019). Consumers' perception on corporate social responsibility: Evidence from Vietnam. Corporate Social Responsibility and Environmental Management, 26(6), 1272-1284.

[21] ISO 26000 (2010). Normes internationales, http://www.iso.org

[22] Khamah, A. H., Njehia, B. K., Njanja, L. W. (2015). Investigating effect of corporate social responsibility on consumer buying behaviour a survey of listed companies in Kenya. International Journal of Economics, Commerce and Management, III(1), 1-20.

[23] Kotler, P. (1994) Marketing Management Analysis, Planning, Implementation, and control, Prentice Hall International Edition, Eight Edition

[24] Kurniawati, A., Samadhi, T. A., Wiratmadja, I. I., Sunaryo, I., Soesanto, R. P., \& Muhammad, F. (2018). Corporate social performance: A multi-stakeholder analysis of Indonesian energy companies' sustainability report. International Journal of Trade Economics and Finance, 9, (3),

[25] Maignan, I., \& Ferrell, O. C. (2004). Corporate Social Responsibility and Marketing: An Integrative Framework. Journal of The Academy of Marketing Science, 32, 3-19

[26] Matten, D., \& Moon, J. (2004). Implicit and explicit CSR: A conceptual framework for understanding CSR in Europe. ICCSR Research Paper Series (29), University of Nottingham.

[27] Mitchell (1997). Toward a theory of stakeholder identification and salience: Defining the principles of who and what really counts. Academy of Management Review, 22(4), 853-886.

[28] Mobile Telephone Network - MTN (2021). 20 Years of Mobile Telephony: MTN Cameroon's excellent contribution rewarded, https://mtn.cm/2021/05/19/20-years-of-mobile-telephony, accessed 15 October 2021

[29] Moskolaï, D. D., Tsapi, V. \& Feudjo J. R. (2016). Etat des lieux de la Responsabilité Sociétale des Entreprises au Cameroun. Management \& Avenir, 4(86), 139-162.

[30] Mulaessa, N. \& Wang, H. (2017). The effect of corporate social responsibility (CSR) activities on consumers purchase intention in China: Mediating role of consumer support for responsible business. International Journal of Marketing Studies, 9(1), 73-81.
[31] Ndzi, E. (2016), Corporate Social Responsibility in Cameroon: The Hydro Electricity Sector, University of Hertfordshire, United Kingdom, African Journal of Business Management, Vol. 10 (7), pp. 151-161, DOI: 10.5897/AJBM2015.7993.

[32] Ngaundje D. L. \& Kwei, H. (2021). Corporate social responsibility in Cameroon: The case of Mobile Telephone Network (MTN). International Journal of Research and Innovation in Social Science, 5(2), 538-545.

[33] Ollong, K. A. \& Ndzi, E. (2016). Analysing the corporate social responsibility strategies by extractive multinational corporations in Cameroon. Social Science and Humanities Journal, 5, 359-397

[34] Pirsch, J., Gupta, S., \& Grau, S. L. (2007). A framework for understanding corporate social responsibility programs as a continuum: An exploratory study. Journal of Business Ethics. 70(2), 125-140

[35] Potluri, R. M., Ullah, R., \& Johnson, S. (2020), Corporate social responsibility and its impact on the Nigerian consumer behavior. Journal of Distribution Science, 18(7), 83-89.

[36] Rahim, R. A., Jalaludin, W. F., \& Tajuddin, K. (2011). The importance of corporate social responsibility on consumer buying behavior in Malaysia. Asian Academy of Management Journal, 16(1), 119-139.

[37] Rampersad, R. \& Skinner, C. (2014). Examining the practice of corporate social responsibility (CSR) in Sub-Saharan Africa. Corporate Ownership and Control, 12(1), 723-732.

[38] Ramya N., \& Mohamed A. S. A. (2016). Factors affecting consumer buying behavior. International Journal of Applied Research. 2(10), 76-80.

[39] Safi, A., \& Ramay, M. I. (2013). Corporate social responsibility and consumer behavior: A study from Pakistan. Information Management and Business Review, 5(4), 194-202.

[40] Sotamenou, D. J. (2014). Corporate social responsibility among small and medium size enterprises in Cameroon. Journal of Entrepreneurship and Innovation Management, 3(2), 1-19.

[41] Srinaruewan, P. (2013). Consumer reactions to corporate social responsibility (CSR) in Thailand. Asia Pacific Journal of Marketing and Logistics, 27(4), 628-652.

[42] Sharma, S. K. \& Sharma, S. (2013). Relationship of corporate social responsibility with consumer buying behaviour: An Indian perspective. Romanian Economic Journal, 16(50), 101-130

[43] Tchatchoua, T., Math, M., \& Djebba, V. (2018), La RSE dans les PME Camerounaises: Etude exploratoire à partir des schèmes cognitifs des propriétaires-dirigeants. Global Journal of Management and Business Research, 18(3), 17-28

[44] Thanh, T. L., Huan, N. H., \& Hong, T. T. T. (2021). Effects of corporate social responsibility on SMEs' performance in emerging market. Cogent Business \& Management, 8, 1878978

[45] Vahdati, H., Mousavi, N. \& Tajik, Z. M. 2015. The study of consumer perception on corporate social responsibility towards consumers attitude and purchase behavior, Asian Economic and Financial Review, 5(5), 831-845.

[46] Yasir, H. \& Amjad, S. A. (2021). Role of Carroll's CSR Pyramid in shaping consumer buying behavior: A case of detergent industry of Pakistan. The Lahore Journal of Business. 9(2), 109140.

[47] Zikmund, W.G. (2003). Business Research Methods. NJ: Thompson South-Western: Ohio. 